\title{
Differential Effects of Tea Extracts on Growth and Cytokine Production by Normal and Leukemic Human Leukocytes
}

\author{
Diana Bayer ${ }^{1}$, Jonathon Jansen ${ }^{1}$, and Lisa A. Beltz ${ }^{2}$ \\ ${ }^{1}$ Department of Biology, University of Northern Iowa, Cedar Falls, IA, USA; ${ }^{2}$ Department of \\ Biology, University of Northern Iowa, Cedar Falls, IA, USA; Department of Biological \\ Sciences, Kent State University at Tuscarawas, New Philadelphia, OH, USA \\ *Corresponding author: Lisa A. Beltz, PhD, Department of Biological Sciences, Kent State \\ University at Tuscarawas, New Philadelphia, OH, USA
}

Submission date: February 23, 2012, Acceptance date: April 15, 2012; Publication date: April 17,2012

\begin{abstract}
$\underline{\text { Abstract }}$
Background: Tea is one of the world's most highly consumed beverages, second only to water. It is affordable and abundant and thus has great potential for improving health of those in both developed and developing areas. Green, oolong, and black teas differ in the extent of fermentation and types of bioactive polyphenols produced. Green tea and its major polyphenol decrease growth of some cancer cells and effect production of immune system cytokines. This study compares the effects of different types of tea extracts on viability and cytokine production by normal and leukemic human $\mathrm{T}$ lymphocytes. Generation of the toxic reactive oxygen species $\mathrm{H}_{2} \mathrm{O}_{2}$ by extracts was also examined.
\end{abstract}

Methods: The Jurkat $\mathrm{T}$ lymphoblastic leukemia cells and mitogen-stimulated normal human peripheral blood mononuclear cells were used in this study. Cell viability was determined by (34,5-dimethylthiamizol-2-yl)-diphenyltetrazolium bromide) assay and production of interleukin-2 by Enzyme-Linked ImmunoSorbent Assay. Levels of $\mathrm{H}_{2} \mathrm{O}_{2}$ generated by tea extracts were determined using the xylenol-orange method.

Results: We found that green, oolong, and black tea extracts differentially effect the growth and viability of $\mathrm{T}$ lymphoblastic leukemia cells and normal peripheral blood mononuclear cells, substantially decreasing both growth and viability of leukemic $\mathrm{T}$ lymphocytes and having much lesser effects on their normal counterparts. Tea extracts also had differential effects on the production of the $\mathrm{T}$ lymphocyte growth factor interleukin-2, significantly decreasing production by leukemic cells while having only minor effects on normal cells. All three extracts induced $\mathrm{H}_{2} \mathrm{O}_{2}$ generation, with green and oolong tea extracts having the greatest effect. Leukemic cells were much more susceptible to growth inhibition and killing by $\mathrm{H}_{2} \mathrm{O}_{2}$ than normal lymphocytes. 
Conclusions: The three tea extracts studied altered leukemic $\mathrm{T}$ lymphocyte functions, decreasing cell viability, growth, and production of a major cell growth factor and the $\mathrm{H}_{2} \mathrm{O}_{2}$ generated by solutions of extracts may be partially responsible. Normal cells were affected to a far lesser degree by tea extracts and are also more resistant to killing by $\mathrm{H}_{2} \mathrm{O}_{2}$ than leukemic cells. This study has implications for using tea extracts for chemotherapeutic and immunomodulatory purposes.

Key Words: Tea extracts, interleukin-2, hydrogen peroxide, leukemia, $\mathrm{T}$ lymphocytes

\section{BACKGROUND:}

Tea is one of the world's most highly consumed beverages, second only to water [1]. It is both affordable and abundant and thus has great potential for improving the health of those living in both developed and developing areas. Green, oolong, and black teas are derived from Camillia sinensis by different processing methods and contain different bioactive polyphenols. Black tea is fully "fermented" by the enzyme polyphenol oxidase to produce theaflavins and thearugins while green tea is not fermented and contains primarily epicatechin, epicatechin gallate, epigallocatechin, and epigallocatechin gallate (EGCG), the latter being the most abundant and bioactive [1]. Oolong tea is only partially fermented and contains theasinensins [2] in addition to intermediate levels of the other polyphenols. A great deal of literature has described the beneficial effects of EGCG in the treatment or prevention of a variety of human diseases, including cancer, obesity and type 2 diabetes, neurodegenerative diseases, and bacterial and viral infections [reviewed by 3]. It is known to alter production of several hormones, neurotransmitters, and immune system cytokines.

Green tea extracts and several green tea polyphenols, especially EGCG, have been reported to kill many types of cancerous cells, including the Jurkat $\mathrm{T}$ lymphocytic leukemia cell line, using a variety of mechanisms, including the activation of proapoptotic caspase-3 [reviewed by 3 ; 4]. EGCG also decreases the production of the T lymphocyte growth factor interleukin-2 [5]. One of the mechanisms for inducing apoptosis in these cells is via the pro-oxidative effects of the reactive oxygen species (ROS) molecule $\mathrm{H}_{2} \mathrm{O}_{2}$ since killing of Jurkat cells is blocked by the enzyme catalase, which degrades $\mathrm{H}_{2} \mathrm{O}_{2}$ into water and $\mathrm{O}_{2}$ [4;6]. If $\mathrm{H}_{2} \mathrm{O}_{2}$ is involved in leukemic cell death and growth inhibition induced by EGCG, it is reasonable to hypothesize that this green tea compound induces its production. Nakagawa et al [4] demonstrated that EGCG does induce a transient increase in $\mathrm{H}_{2} \mathrm{O}_{2}$ levels when present in tissue culture medium, peaking at 30 minutes. EGCG induces the production of other ROS as well, including the superoxide and hydroxyl ions [7]. EGCG also affects Jurkat cell viability without directly involving ROS, including altering enzymatic activity of proteasomes [8].

EGCG has also been shown to preferentially kill a variety of cancerous cells but not their normal counterparts [8]. This report will focus on the differential effects of tea extracts upon growth, viability, and cytokine production by normal human peripheral blood mononuclear cells (PBMC) and Jurkat T lymphocytic leukemia cells. While little research has examined the effects of EGCG upon normal lymphocytes, this polyphenol has been found to increase production of the $\mathrm{T}$ cell cytokine interleukin-2 (IL-2) by normal cells [9]. IL-2 is a key cytokine that up- 
regulates either growth or activity of several immune cell types, including $\mathrm{T}$ helper lymphocytes whose cytokines regulate the immune system, $\mathrm{T}$ killer lymphocytes that kill cancerous and virally-infected cells, and B lymphocytes that produce antibodies. Work in my laboratory also suggests that EGCG and several other green tea polyphenols increase production of several other cytokines by normal, but not leukemic, T lymphocytes (not shown).

In this report, we compared and contrasted the effects of green, oolong, and black tea extracts on growth, viability, and cytokine production by normal and leukemic human T cells. We also compared the ability of various levels of these different types of tea extracts to generate $\mathrm{H}_{2} \mathrm{O}_{2}$ and the ability of these normal and cancerous cell types to withstand insult by $\mathrm{H}_{2} \mathrm{O}_{2}$. Our findings expand upon the previous work performed with individual tea polyphenols and compare anticancer activity of the three major types of tea consumed throughout the world.

\section{MATERIALS AND METHODS:}

\section{Tea extracts:}

Green (Bancha), oolong, and black (Darjeeling) tea extracts were lyophilized, then resuspended at various concentrations in RPMI 1640 tissue culture medium (Gibco BRL) containing 10\% fetal bovine serum (Hyclone) and $100 \mathrm{U} / \mathrm{ml}$ penicillin/streptomycin and L-glutamine (Gibco BRL) (complete medium).

\section{Cells:}

The Jurkat T lymphoblastic leukemia cell line was purchased from the American Type Culture Collection. They were maintained and cultured in complete medium. Prior to usage, cells were counted in a hemocytometer and viability determined using trypan blue dye exclusion.

Blood was drawn by venipuncture from normal healthy volunteers after obtaining informed consent in accordance with the Helsinki Declaration and the policies of the Human Subjects Review Committee of the University of Northern Iowa. Universal precautions were followed when handling human blood and blood products. PBMC were isolated by density gradient centrifugation over a layer of Ficoll-Hypaque (density $=1.007$ ). Viable cells were enumerated as above and resuspended in complete medium. PBMC were stimulated by addition of $4 \mu \mathrm{g} / \mathrm{ml}$ phytohemagglutinin (PHA).

\section{Proliferation and viability assays:}

Jurkat cells $\left(2 \times 10^{5}\right.$ cells $\left./ \mathrm{ml}\right)$ and PBMC $\left(2 \times 10^{6}\right.$ cells $\left./ \mathrm{ml}\right)$ were plated in a total volume of $100 \mu \mathrm{l}$ in triplicate wells of flat-bottomed 96-well plates in the presence or absence of various concentrations of tea extracts or $\mathrm{H}_{2} \mathrm{O}_{2}$ in complete medium. Cultures were incubated in a humidified $37^{\circ} \mathrm{C}, 5 \% \mathrm{CO}_{2}$-in-air incubator for 96 hours. In order to determine the amount of cell proliferation, $1 \mu \mathrm{Ci}{ }^{3} \mathrm{H}$-thymidine was then added to each well. After 4 hours of further incubation, DNA from the cells was deposited onto filter strips and washed using a plate harvester. Levels of ${ }^{3} \mathrm{H}$-thymidine incorporated into the DNA was assessed using a $\beta$ scintillation counter with Scinti-Safe scintillation fluor (Fisher) and results presented as counts per minute $(\mathrm{cpm})$. Relative numbers of cpm reflect the amount of DNA synthesis, and thus proliferation, which occurred. In order to determine relative amounts of viable cells, 96-hour cultures were pulsed with $25 \mu \mathrm{l}$ of the yellow tetrazolium dye (3-4,5-dimethylthiamizol-2-yl)- 
diphenyltetrazolium bromide) (MTT) $(5 \mu \mathrm{g} / \mathrm{ml})$. One hundred $\mu \mathrm{l}$ of $0.04 \% \mathrm{HCl}$ in isopropanol was added to the cells 4 hours later. Cultures were read in a plate-reading spectrophotometer at $570 \mathrm{~nm}$ and results expressed as optical density (OD). In the presence of active mitochondria, the yellow dye is converted into a purple formazan product. The higher the OD at $570 \mathrm{~nm}$, the greater was the number of functional mitochondria, and thus the greater the number of live cells.

\section{$\mathrm{H}_{2} \mathrm{O}_{2}$ determination:}

Varying amounts of tea extracts were incubated at $37^{\circ} \mathrm{C}$ in complete medium for 30-60 minutes. Levels of $\mathrm{H}_{2} \mathrm{O}_{2}$ present in the cell-free medium were determined using the xylenol-orange method as described by Nakagawa et al [4]. Briefly, $30 \mu \mathrm{l}$ of the solution was added to $300 \mu \mathrm{l}$ of indicator solution. After a 20-minute incubation at room temperature, $90 \mu \mathrm{l}$ was added to triplicate wells of a 96-well plate. The plate was read at a wavelength of $595 \mathrm{~nm}$. An 8-point $\mathrm{H}_{2} \mathrm{O}_{2}$ standard curve was run in parallel, and levels of $\mathrm{H}_{2} \mathrm{O}_{2}$ were determined by linear regression analysis. Results were expressed as $\mu \mathrm{M} \mathrm{H}_{2} \mathrm{O}_{2}$.

\section{IL-2 Production and Assay:}

Jurkat cells $\left(2 \times 10^{5}\right.$ cells $\left./ \mathrm{ml}\right)$ and PBMC $\left(2 \times 10^{6}\right.$ cells $\left./ \mathrm{ml}\right)$ were stimulated to produce IL-2 by the presence of a combination of phorbol myristal acetate $(50 \mathrm{ng} / \mathrm{ml}$; Sigma) and PHA $(4 \mu \mathrm{g} / \mathrm{ml})$ or PHA alone, respectively. After a 24-hour incubation at $37^{\circ} \mathrm{C}$, culture supernatants were removed and stored at $-20^{\circ} \mathrm{C}$ until assayed. Levels of IL-2 were determined by antigen-capture EnzymeLinked ImmunoSorbent Assay (ELISA) in accordance with the manufacturer's instructions (R \& D Systems).

\section{Statistical analysis:}

Samples were assayed in triplicate determinations and each experiment performed two to three times, with a representative experiment being shown. Statistical analysis was performed using Student's t-test with Excel software. p values $<0.05$ were considered statistically significant. Standard deviations for the data were consistently less than $10 \%$.

\section{RESULTS:}

\section{Effects of Tea Extracts on Growth and Viability of Normal and Leukemic T Lymphocytes:}

Extracts of green, oolong, and black teas significantly and equally decreased growth of Jurkat $\mathrm{T}$ lymphocytic leukemia cells after 96 hours at concentrations $\geq 25 \mu \mathrm{g} / \mathrm{ml}$ (38-45\% decrease; $\mathrm{p}<0.001$ ) (Figure 1a). At a concentration of $200 \mu \mathrm{g} / \mathrm{ml}$ tea extract, the decrease in Jurkat cell proliferation was 96-98\%. In contrast, tea extracts decreased growth of normal human PBMC to a far lesser degree (decrease of $21-44 \%$ at $200 \mu \mathrm{g} / \mathrm{ml}$ tea) (Figure $1 \mathrm{~b}$ ).

Differential effects of tea extracts on normal and leukemic $\mathrm{T}$ lymphocyte viability were also found although higher concentrations of extract were necessary to produce the effects. At a concentration of $200 \mu \mathrm{g} / \mathrm{ml}$ of any of the tea extracts, Jurkat cell viability decreased (Figure 1c). PBMC viability was instead slightly increased at $100-200 \mu \mathrm{g} / \mathrm{ml}$ extract (Figure 1d).

Figure 1. Growth and Viability of Leukemic and Normal Lymphocytes by Green, Oolong, and Black Tea Extracts. Growth of the leukemic Jurkat cell line (Figure 1a) or normal PHA- 
stimulated PBMC (Figure 1b) was determined by the incorporation of ${ }^{3} \mathrm{H}$-thymidine into DNA after a 96-hour exposure to several concentrations of tea extracts. Results are expressed as cpm. Error bars represent 1 standard deviation above and below the mean. Viability of leukemic Jurkat cell line (Figure 1c) or normal PHA-stimulated PBMC (Figure 1d) was determined by the MTT colorimetric assay after a 96-hour exposure to several concentrations of tea extracts. Results are expressed as OD at $570 \mathrm{~nm} .{ }^{*} \mathrm{p}<0.05 ;{ }^{*} \mathrm{p}<0.01$.

\section{Figure 1a}

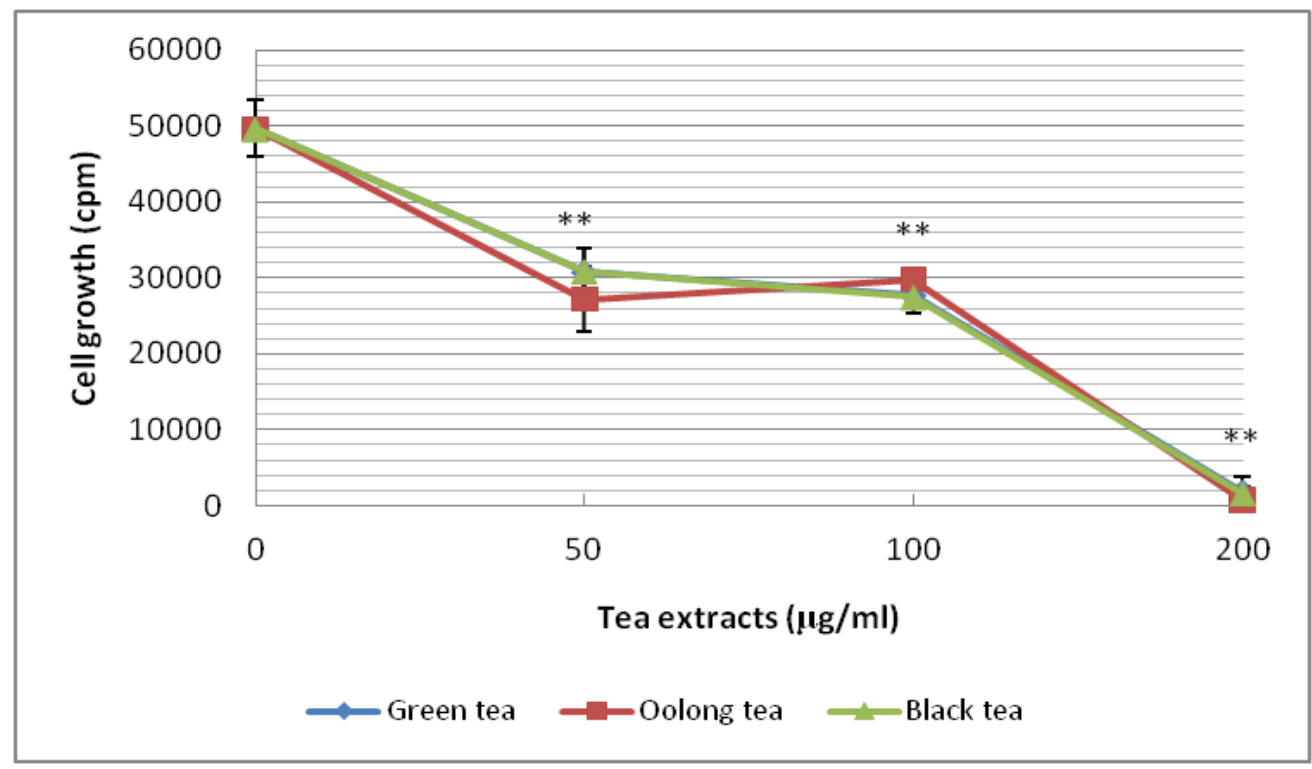

\section{Figure 1b}

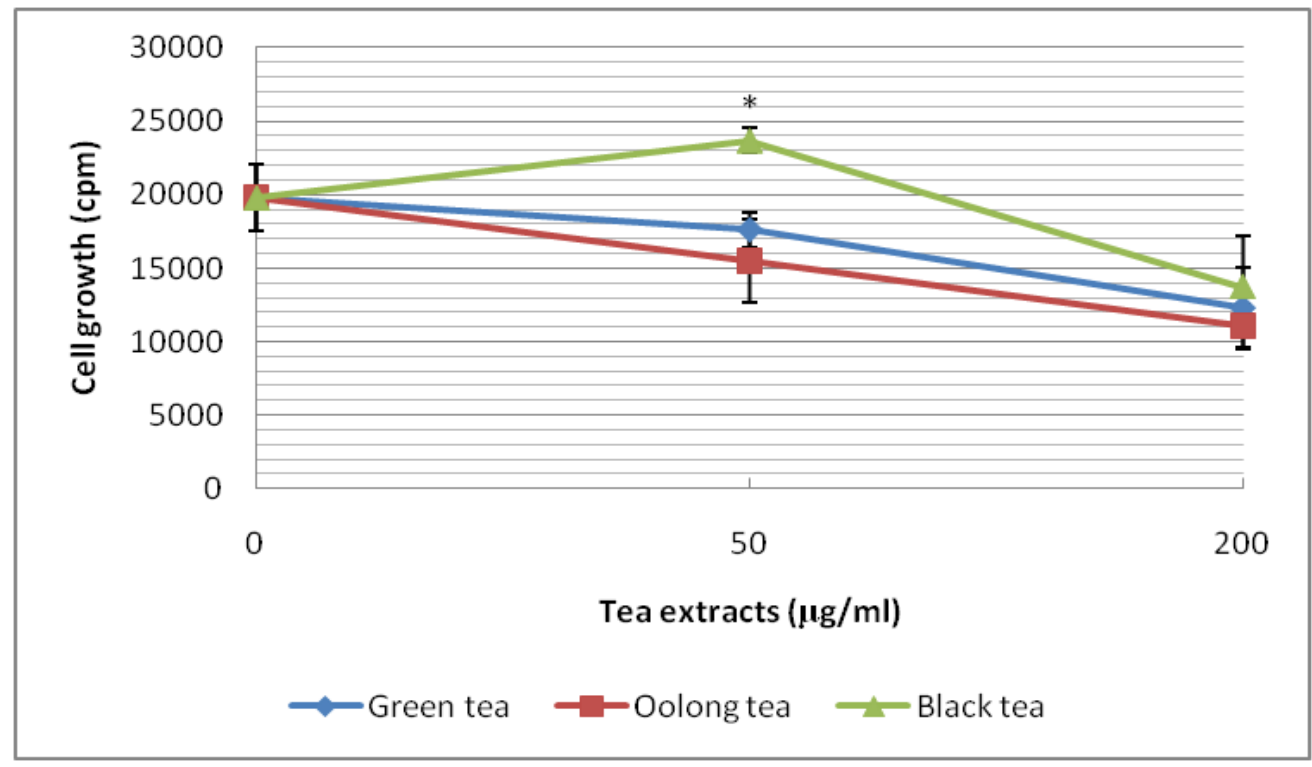

Figure 1c 


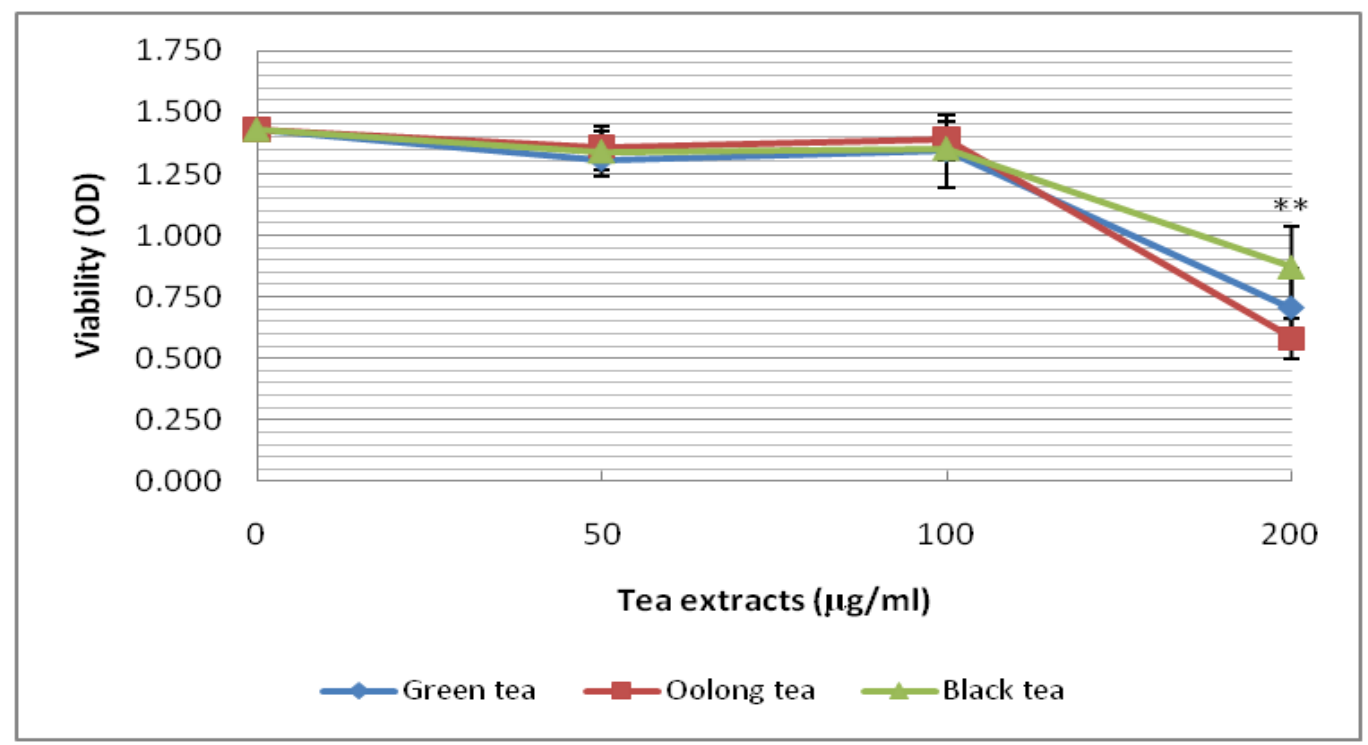

Figure 1d

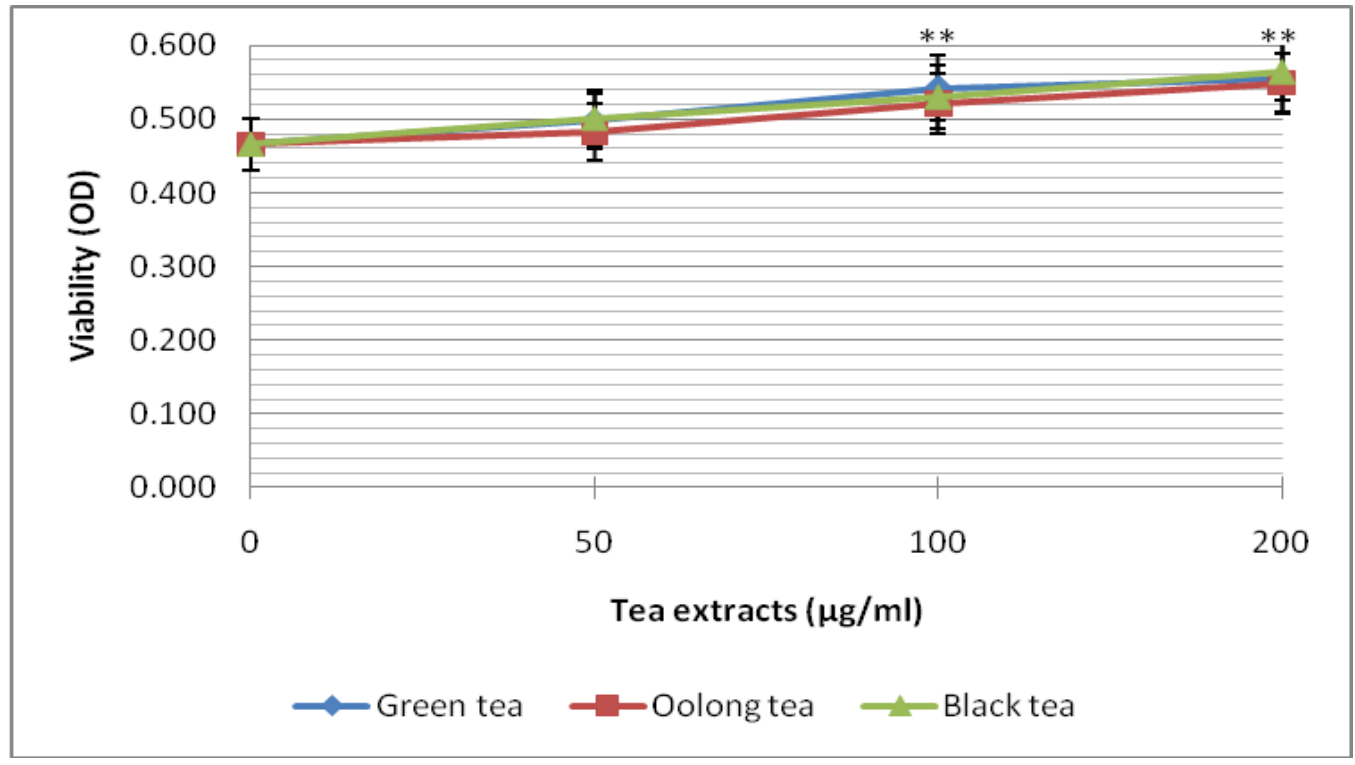

\section{Generation of $\mathrm{H}_{2} \mathrm{O}_{2}$ by Tea Extracts:}

The presence of $100-200 \mu \mathrm{g} / \mathrm{ml}$ tea extracts in tissue culture medium generated significant amounts of $\mathrm{H}_{2} \mathrm{O}_{2}$ after as little as 30 to 60 minutes, with green and oolong teas producing higher levels than black tea extract (Figures 2a and 2b). Concentrations of $\mathrm{H}_{2} \mathrm{O}_{2}$ increased as the time of culture increased. In contrast, red tea extract, a strong antioxidant, did not generate significant amounts of $\mathrm{H}_{2} \mathrm{O}_{2}$ in our assay at concentrations of up to $200 \mu \mathrm{g} / \mathrm{ml}$ after 60 minutes (not shown). It should be noted that a 96-hour exposure to tea extracts decreased the growth but not viability of Jurkat cells at concentrations which not did induce significant $\mathrm{H}_{2} \mathrm{O}_{2}$ generation after 1 hour. This suggests that tea extracts may also be inhibiting leukemic cell growth in a manner independent of ROS as previously suggested [10]. In support of this hypothesis, we also found 
that growth inhibitory effects of the major green tea polyphenol, EGCG, on Jurkat cell growth are substantially, but not totally reversed by the exogenous catalase, an enzyme that degrades $\mathrm{H}_{2} \mathrm{O}_{2}$ (50-60\% of growth restored) (unpublished data). Alternatively, significantly inhibitory levels of $\mathrm{H}_{2} \mathrm{O}_{2}$ may be produced by lower levels of tea extracts after 96 hours.

Figure 2. $\mathrm{H}_{2} \mathrm{O}_{2}$ Generation by Tea Extracts. Green, oolong, and black tea extracts were incubated for 30 minutes (Figure 2a) or 60 minutes (Figure 2b) in complete medium. Levels of $\mathrm{H}_{2} \mathrm{O}_{2}$ were then measured using the xylenol-orange colorimetric assay. A standard curve was run in parallel and the amount of $\mathrm{H}_{2} \mathrm{O}_{2}$ in the test samples was determined by linear regression analysis and expressed as $\mu \mathrm{M} \mathrm{H}_{2} \mathrm{O}_{2}$. Error bars represent 1 standard deviation above and below the mean. ${ }^{*} \mathrm{p}<0.05 ;{ }^{*} \mathrm{p}<0.01$.

Figure 2a

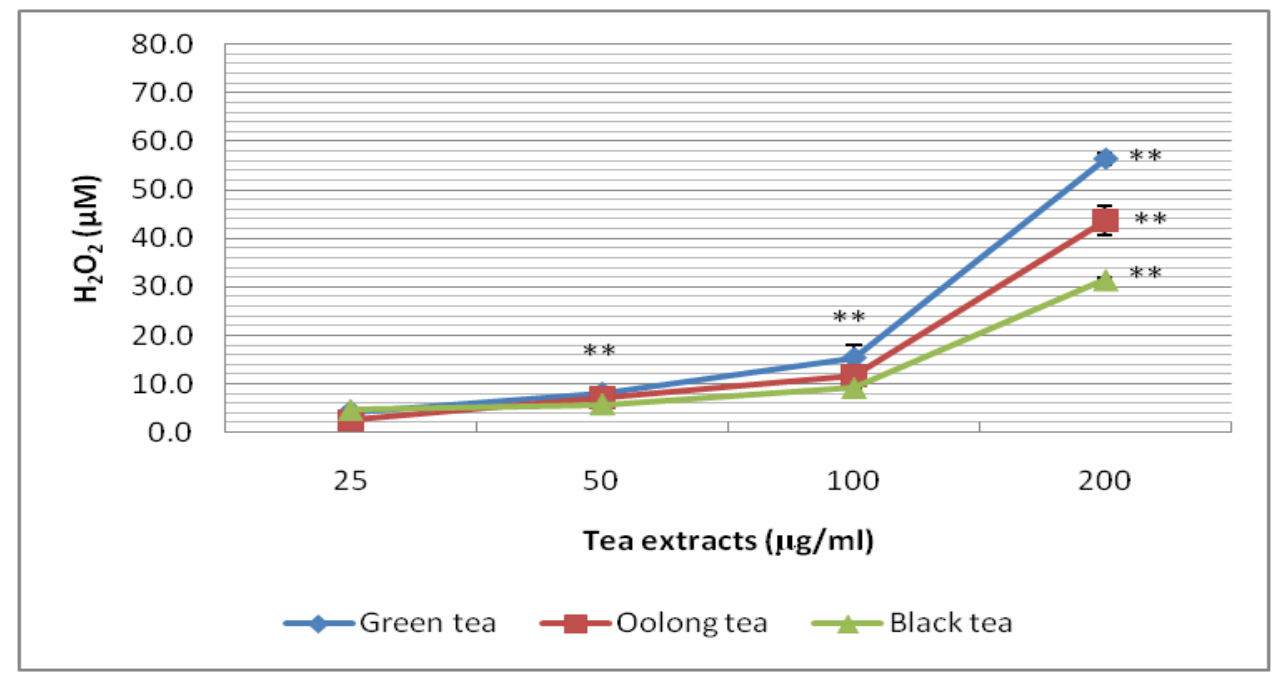

Figure 2b

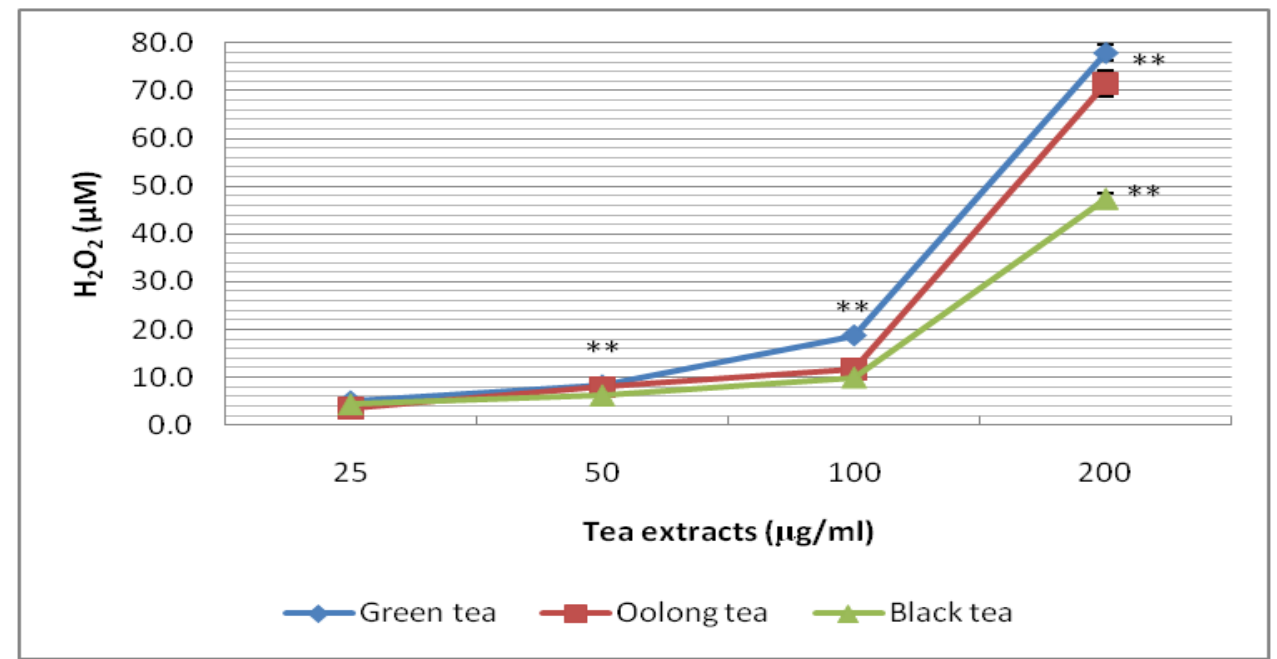

$\mathrm{H}_{2} \mathrm{O}_{2}$ and Growth of Normal and Leukemic T Lymphocytes: 
Various amounts of exogenous $\mathrm{H}_{2} \mathrm{O}_{2}$ were added directly to cultures of leukemic Jurkat cells or PBMC and cell growth was determined 96 hours later. The growth of leukemic cells was significantly decreased by concentrations of $\mathrm{H}_{2} \mathrm{O}_{2} \geq 25 \mu \mathrm{M}(91 \%$ growth decrease at $25 \mu \mathrm{M})$. In comparison, growth of PBMC from most normal donors was relatively unaffected by up to 200 $\mu \mathrm{M} \mathrm{H}_{2} \mathrm{O}_{2}$ (Figure 3). It should be noted, however, that sensitivity of PBMC varied among donors, with some individuals' cells being affected by this amount of $\mathrm{H}_{2} \mathrm{O}_{2}$ (unpublished data).

Figure 3. Growth of Leukemic and Normal T Lymphocytes by Exogenous $\mathrm{H}_{2} \mathrm{O}_{2}$. Growth of the leukemic Jurkat cell line or normal PHA-stimulated PBMC was determined by the incorporation of ${ }^{3} \mathrm{H}$-thymidine into DNA after a 96-hour exposure to several concentrations of $\mathrm{H}_{2} \mathrm{O}_{2}$. Results are expressed as cpm. Error bars represent 1 standard deviation above and below the mean. * $\mathrm{p}<0.05 ; * \mathrm{p}<0.01$.

Figure 3

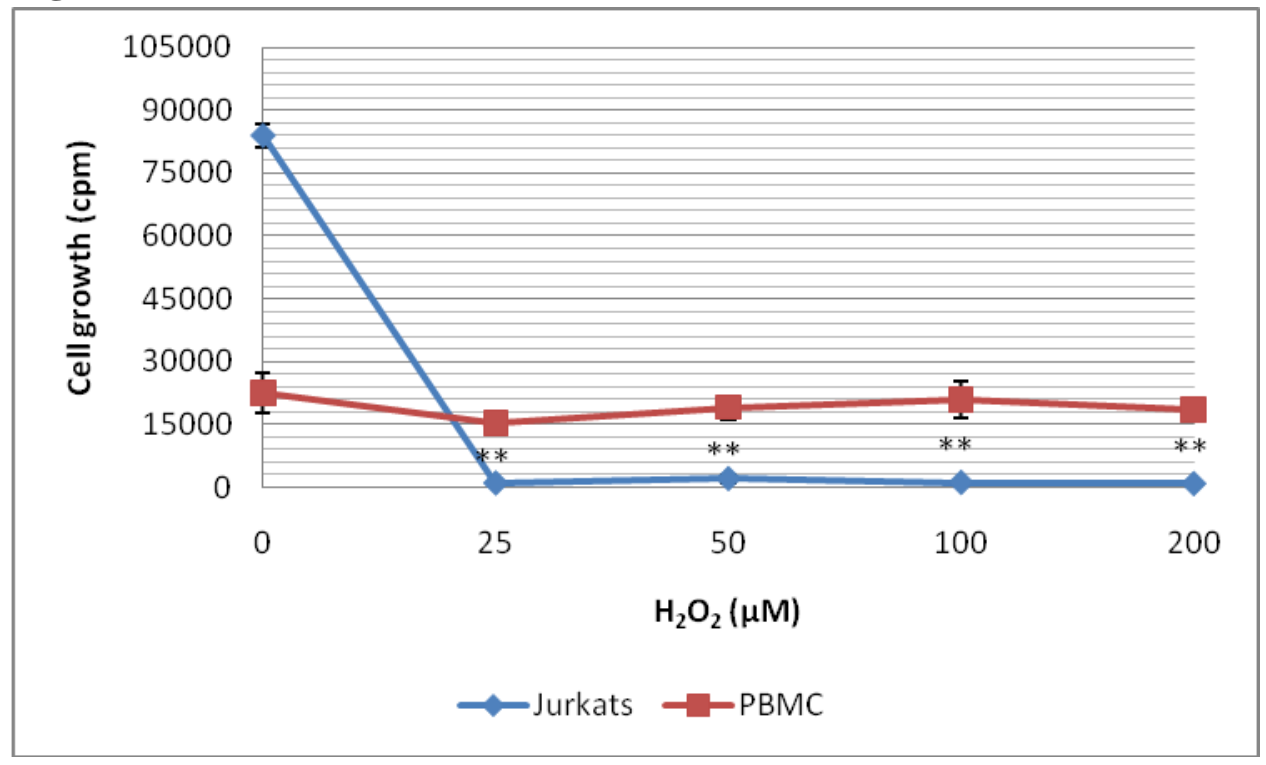

\section{Effects of Tea Extracts on IL-2 Production By Normal and Leukemic T Lymphocytes:}

Tea extracts differentially alter the production of the cytokine IL-2 by stimulated Jurkat $\mathrm{T}$ lymphoblastic leukemia cells and normal PBMC stimulated by PHA, a T cell mitogen. Green, oolong, and black tea extracts equally decreased IL-2 production by Jurkat cells in a dosedependent manner (50 to $200 \mu \mathrm{g} / \mathrm{ml}$ tea) (Figure 4a). IL-2 production by PBMC, in contrast, was significantly increased by $100 \mu \mathrm{g} / \mathrm{ml}$ (black) or $200 \mu \mathrm{g} / \mathrm{ml}$ (oolong) tea but not by green tea extracts (Figure 4b). IL-2 production (24-hour) was again inhibited at tea concentrations below that which induced significant generation of $\mathrm{H}_{2} \mathrm{O}_{2}$ after 1 hour.

Figure 4. IL-2 Production by Leukemic and Normal Lymphocytes by Green, Oolong, and Black Tea Extracts. IL-2 production by the leukemic Jurkat cell line (Figure 4a) or normal PHAstimulated PBMC (Figure 4b) was determined by ELISA. A standard curve was run in parallel and the amount of IL-2 in the test samples was determined by linear regression analysis and expressed as pM IL-2. Error bars represent 1 standard deviation above and below the mean. 
Figure 4a

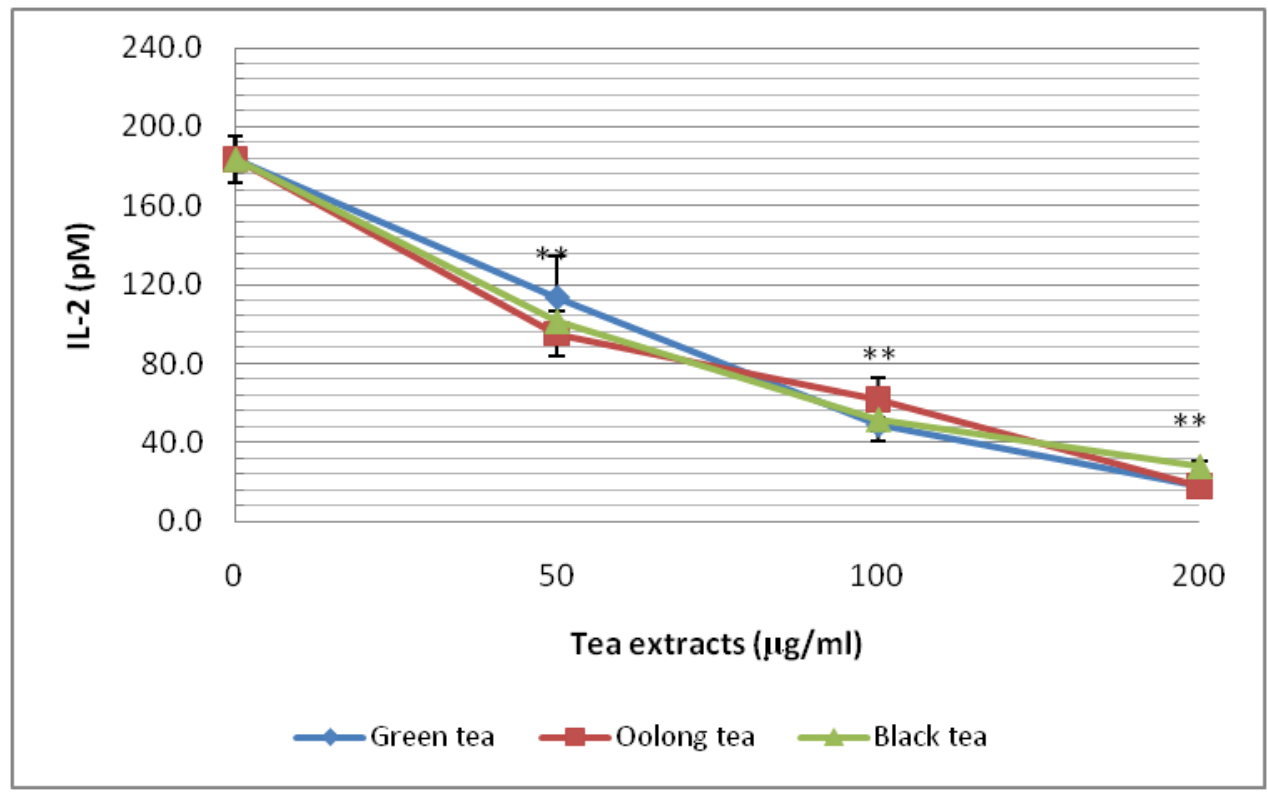

\section{Figure 4b}

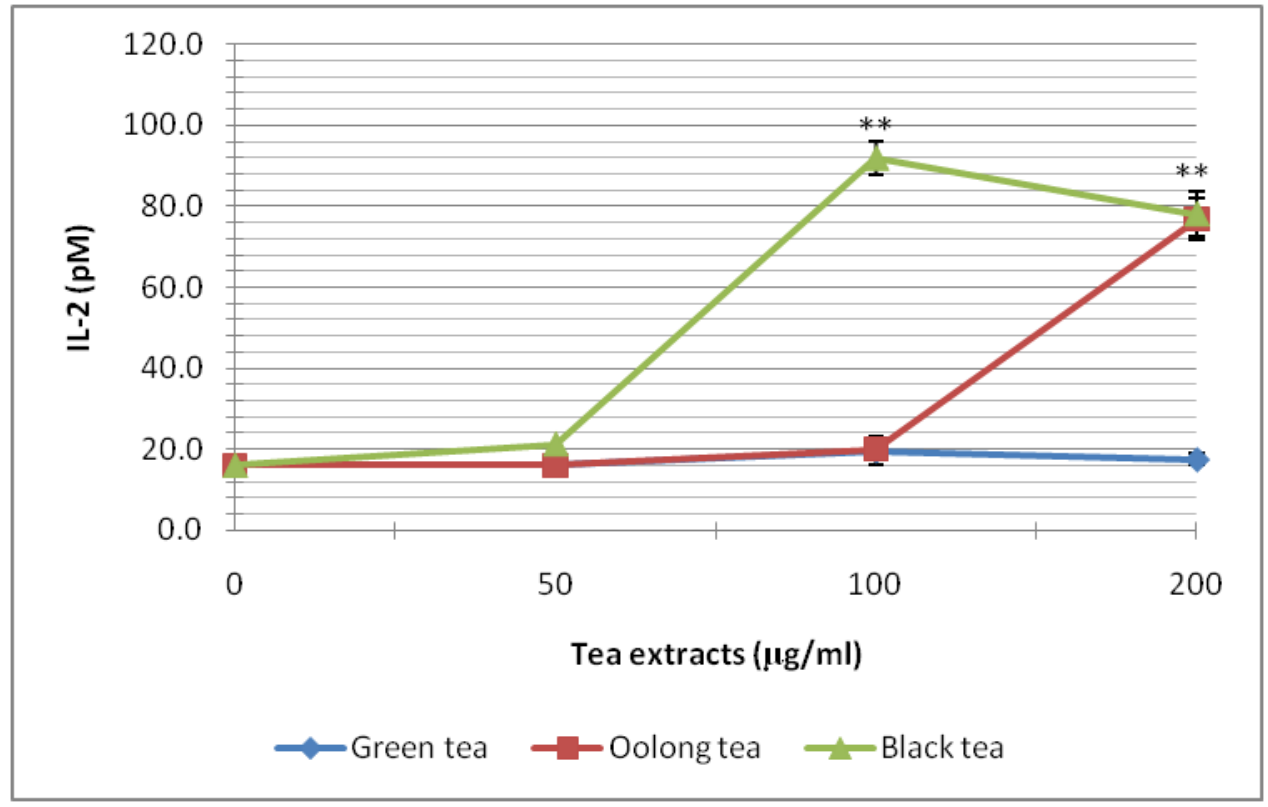

\section{DISCUSSION:}

We report herein that green, oolong, and black tea extracts decrease both growth and viability of the Jurkat leukemic $\mathrm{T}$ lymphocyte line, with a much more profound decrease in growth as compared to viability, perhaps due to the complex nature of the relationship between $\mathrm{H}_{2} \mathrm{O}_{2}$ and proliferation. A much smaller effect was seen on the corresponding normal human cells. A number of bioactive compounds are present in tea, and differ among tea types due to differences in processing of the leaves. Other investigators have previously found that ECGC and several 
other green tea polyphenols decrease the viability of Jurkat cells $[4 ; 6 ; 8]$. Interestingly, theasinensins from oolong tea and some of black tea theaflavins also suppress Jurkat cell growth, and do so to a greater extent than EGCG [11].

EGCG has been reported to decrease the growth of normal murine spleen-derived $\mathrm{T}$ lymphocytes due, at least in part, by decreasing levels of the IL-2 receptor. As in the current study, viability of the normal T lymphocytes was not decreased [12]. Wu et al [13] also found that high levels of ECGC $(100 \mu \mathrm{M})$ up-regulated IL-2 RNA levels in Jurkat cells. We found that EGCG at lower concentrations $(20-40 \mu \mathrm{M})$ instead decreases IL-2 production by Jurkat cells (unpublished data), revealing concentration-dependent differences in EGCG actions. In the present study, we found that tea extracts greatly decreased levels of IL-2 protein produced by Jurkat cells while black and oolong tea extracts increased its production by normal PBMC. The lack of such an effect by green tea extracts might relate to differences in $\mathrm{H}_{2} \mathrm{O}_{2}$ generation by the different kinds of tea.

In addition to tea compounds, a number of other plant-based medicinals from functional foods act as either anti- or pro-oxidants, depending upon their concentration. These include resveratrol from red wine, lycopenes and Vitamin $\mathrm{C}$ from tomato products, genistein from soy, the extract of the fruit of Gleditsia sinensis and Baizhu (Atractylodes macrocephala Koidz), takrisodokyeum, and jasmonates [14-21]. Interestingly, low amounts of EGCG or green tea extract $(10 \mu \mathrm{g} / \mathrm{ml})$ appear to protect leukemic cells against $\mathrm{H}_{2} \mathrm{O}_{2}$-induced DNA breakage, while higher levels of EGCG alone induce strand breakage instead [22-23]. ROS generation by individual green tea polyphenols occurred at concentrations of EGCG greater than $20 \mu \mathrm{M}$. When lower concentrations of EGCG were used instead, an anti-oxidant effect was observed [reviewed by 24]. ROS generation by phorbol myristal acetate-stimulated HeLa cervical carcinoma cells, HL-60 promyelocytic leukemia cells, and normal skin fibroblasts was inhibited by at low concentrations of EGCG (1-10 $\mu \mathrm{M})$ [25-27]. Lymphocytes derived from volunteers whose diet was supplemented with green tea were also protected against $\mathrm{H}_{2} \mathrm{O}_{2}$-mediated DNA damage [28].

EGCG has been previously reported to preferentially kill cancer cells. Such differential killing is a property of the plant stress hormone family of jasmonates as well, which also differentially suppresses proliferation of malignant blood cells of chronic lymphocytic leukemia patients while sparing that of the normal cells present [14]. Such effects may be mediated through ROS. In one study, EGCG was found to increase levels of ROS in oral carcinoma cells but decrease ROS in normal salivary gland cells [29]. More recent studies have shown that the low levels of $\mathrm{H}_{2} \mathrm{O}_{2}$ generated in cells by EGCG protect against cell death in a nontumorogenic keratinocyte cell line but not in promyelocytic leukemia cells [30]. Low levels of $\mathrm{H}_{2} \mathrm{O}_{2}$ have been shown to function in intracellular signal transmission and protect rather than damage normal cells [31]. Taken together, these results suggest that EGCG and tea extracts may have anti-oxidant and cytoprotective effects at low concentrations, but it instead stimulate $\mathrm{H}_{2} \mathrm{O}_{2}$ production at higher concentrations, as previously suggested [3]. Green, oolong, and black tea extracts contain high, medium, and low amounts of EGCG [reviewed by 3]. They also induce $\mathrm{H}_{2} \mathrm{O}_{2}$ production in the same relative order. Their differential ability to generate $\mathrm{H}_{2} \mathrm{O}_{2}$ could be due to differing levels of EGCG in the various extracts. $\mathrm{H}_{2} \mathrm{O}_{2}$ generated by tea extracts thus appeared to play a role in Jurkat cell, but not normal PBMC, growth suppression. Since growth inhibition of this leukemic cell type occurred at tea concentrations that may produce relatively 
low levels of $\mathrm{H}_{2} \mathrm{O}_{2}$, other mechanisms may also be involved. In other leukemic cell types, ROS production may be the sole growth-suppressive factor (unpublished data).

This study demonstrated that direct addition of $\mathrm{H}_{2} \mathrm{O}_{2}$ to Jurkat cell cultures inhibited their proliferation and, soon after, their viability (the latter is not shown). These cancerous cells were much more sensitive to growth inhibition than normal PBMC. A study by Yamamoto et al [29] suggests that normal cells (salivary gland cells) contain higher levels of catalase, an enzyme that degrades $\mathrm{H}_{2} \mathrm{O}_{2}$, than do oral carcinoma cells, allowing the former to more readily remove toxic ROS, including those produced by tea extracts and EGCG. Their results are in agreement with work from our laboratory that shows that normal PBMC are better able to degrade $\mathrm{H}_{2} \mathrm{O}_{2}$ than a number of different types of leukemia cells, including $\mathrm{T}$ and $\mathrm{B}$ lymphocytic leukemia, natural killer cell leukemia, and erythroleukemia cells (unpublished data). When $100 \mu \mathrm{M} \mathrm{H}_{2} \mathrm{O}_{2}$ was incubated in the presence of Jurkat T lymphocytic leukemia cells, an average of $37 \%$ of the $\mathrm{H}_{2} \mathrm{O}_{2}$ was removed after 30 minutes. Normal human PBMC vary considerably among individuals. When $\mathrm{H}_{2} \mathrm{O}_{2}$ was incubated with PBMC from normal donors, an average of $56 \%$ was removed in the same time period, but the range was quite large (31-91\% using cells from 7 donors). Interestingly, the ability of different types of leukemia cells to degrade $\mathrm{H}_{2} \mathrm{O}_{2}$ is inversely correlated with their susceptibility to killing by green tea polyphenols (unpublished data). The enzyme responsible for $\mathrm{H}_{2} \mathrm{O}_{2}$ degradation likely differs according to the type of leukocyte tested and may involve catalase, a peroxidase, or both.

It should be noted that, unlike previous reports, our study used tea extracts rather than ECGC itself. We have found that combinations of green tea polyphenols (EGCG and epicatechin) may have additive or synergistic effects on growth and cytokine production by normal and leukemic T lymphocytes (unpublished data). This suggests that tea extracts may be more active than purified tea polyphenols. This is encouraging from a public health prospective since much of the world's population may be able to afford tea but not purified derivatives. Future research could explore which of the many ways of processing tea leaves and which specific strains of teas are most beneficial for human health.

\section{CONCLUSIONS:}

We demonstrated that green, oolong, and black tea extracts differentially alter growth and viability of normal and leukemic human $\mathrm{T}$ lymphocytes, perhaps partially resulting from their pro-oxidant activities. Additionally, normal and leukemic cells are differentially susceptible to the damaging effects of $\mathrm{H}_{2} \mathrm{O}_{2}$. Since a number of chemotherapeutic agents rely upon generation of this reactive oxygen species, our findings are potentially of additional clinical significance.

We also showed that tea extracts decreased production of the T lymphocyte growth factor IL-2 by leukemic cells while increasing production by normal cells. In separate studies, we have seen that green tea polyphenols also increase Jurkat cell production of the regulatory cytokine IL-10 but decrease its production by PBMC from most normal donors tested (unpublished data). Differential effects of EGCG and other tea compounds on production of growth-stimulatory and regulatory cytokines by normal and leukemic cells may be at least partially responsible for their effects on these cells' growth and viability. Further studies are needed to examine the effects of tea extracts on growth and cytokine production by other types of leukemic cells as well as to determine whether tea may have useful immunomodulatory effects. 
Abbreviations: Counts per minute (cpm), Enzyme Linked ImmunoSorbent Assay (ELISA), Epigallocatechin Gallate (EGCG), Interleukin-2 (IL-2), (3-4,5-dimethylthiamizol-2-yl)diphenyltetrazolium bromide) (MTT), Optical Density (OD), Peripheral Blood Mononuclear Cells (PBMC), Phytohemagglutinin (PHA), Reactive Oxygen Species (ROS)

\section{Competing interests:}

The authors declare that they have no competing interests.

\section{Authors' Contributions:}

$\mathrm{LB}, \mathrm{PhD}$, is an Assistant Professor at Kent State University at Tuscarawas. She was the principle investigator for this study and provided oversight, performed some of the experimental work, analyzed part of the data, interpreted the data, and wrote the manuscript. She is a member of the Free Radical Biology and Medicine Society.

DB, DO, performed part of the experimental work for this study and analyzed part of the data.

JJ, DO, performed part of the experimental work for this study and analyzed part of the data.

\section{Acknowledgements and Funding:}

D. Bayer and J. Jansen were supported by the Undergraduate Research Assistantship Program of the Department of Biology and the Summer Undergraduate Research Program of the College of Natural Sciences and the Department of Biology of the University of Northern Iowa. We wish to thank our volunteer blood donors.

\section{REFERENCES:}

1. Wei H, Zhang X, Zhao JF, Wang ZY, Bickers D, Lebwohl M: Scavenging of hydrogen peroxide and inhibition of ultraviolet light-induced oxidative DNA damage by aqueous extracts from green and black teas. Free Radicals Biol Med 1999, 26:1427-1435.

2. Hashimoto F, Nonaka GI, Nishioka I: Tannins and related compounds LXIX. Isolation and structure elucidation of B,B'-linked bisflavanoids, theasinensins D-G and Oolong theanin from oolong tea. Chem Pharm Bull 1988, 36:1676-1684.

3. Beltz LA, Bayer DK, Moss AL, Simet IM: Mechanisms of cancer prevention by green and black tea polyphenols. Anti-Cancer Agents in Medicinal Chem 2006, 6:389-406.

4. Nakagawa H, Hasumi K, Woo J-T, Nagai K, Wachi M: Generation of hydrogen peroxide primarily contributes to the induction of $\mathrm{Fe}(\mathrm{II})$-dependent apoptosis in Jurkat cells by (-)epigallocatechin gallate. Carcinogenesis (London) 2004, 25:1567-1574.

5. Shim J-H, Choi HS, Pugliese A, Lee S-Y, Chae J-I, Choi BY, Bode AM, Dong Z: (-)Epigallocatechin gallate regulates $\mathrm{CD} 3$-mediated $\mathrm{T}$ cell receptor signaling in leukemia through the inhibition of ZAP-70 kinase. J Biol Chem 2008, 283:28370-28379.

6. Lee YK, Bone ND, Strege AK, Shanafelt TD, Jelinek DF, Kay NE: VEGF receptor phosphorylation status and apoptosis is modulated by a green tea component, 
epigallocatechin-3-gallate (EGCG), in B-cell chronic lymphocytic leukemia. Blood 2004, 104:788-794.

7. Azam S, Hadi N, Khan NU, Hadi SM: Prooxidant properties of green tea polyphenols epicatechin and epicatechin-3-gallate: implications for anticancer properties. Toxicol In Vitro 2004, 18:555-561.

8. Nam S, Smith DM, Dou QP: Ester bond-containing tea polyphenols potently inhibit proteasome activity in vitro and in vivo. J Biol Chem 2001, 276:13322-13330.

9. Lyu S-Y, Park W-B: Production of cytokine and NO by RAW 264.7 macrophages and PBMC in vitro incubation with flavonoids. Arch Pharm Res 2005, 28:573-581.

10. Yamamoto T, Lewis J, Wataha J, Dickinson D, Singh B, Bollag WB, Ueta E, Osaki T, Athar M, Schuster G, Hsu S: Roles of catalase and hydrogen peroxide in green tea polyphenolinduced chemopreventive effects. J Pharmacol Exper Therap 2004, 308: 317-323.

11. Pan M-H, Liang Y-C, Lin-Shiau S-Y, Zhu N-Q, Ho C-T, Lin J-K: Induction of Apoptosis by the Oolong Tea Polyphenol Theasinensin A through Cytochrome c Release and Activation of Caspase-9 and Caspase-3 in Human U937 Cells. J Agric Food Chem 2000, 48:6337-634

12. Wu D, Guo Z, Ren Z, Guo W, Meydani SN: Green tea EGCG suppresses T cell proliferation through impairment of IL-2/IL-2 receptor signaling. Free Radical Biol Med 2009, 47:636643.

13. Wu H, Zhu B, Shimoishi Y, Murata Y, Nakamura Y: (-)-Epigallocatechin-3-gallate induces up-regulation of Th1 and Th2 cytokine genes in Jurkat T cells. Arch Biochem Biophys 2009, 483:99-105.

14. Flescher E: Jasmonates in cancer therapy. Cancer Lett 2007, 245:1-10.

15. Riso P, Visioli F, Erba D, Testolin G, Porrini M: Lycopene and vitamin C concentrations increase in plasma and lymphocytes after tomato intake. Effects on cellular antioxidant protection. Eur J Clin Nutr 2004, 58:1350-8.

16. Foti P, Erba D, Riso P, Spadafranca A, Criscuoli F, Testolin G: Comparison between daidzein and genistein antioxidant activity in primary and cancer lymphocytes. Arch Biochem Biophys 2005, 433:421-7.

17. Ahmad KA, Clement M-V, Hanif I, Pervaiz S: Resveratrol inhibits drug-induced apoptosis in human leukemia cells by creating an intracellular milieu nonpermissive for death execution. Cancer Res 2004, 64:1452-1459.

18. Teo IT, Tang JC, Chui CH, Cheng GY, Yau MY, Yau MY, Lau FY, Wong RS, Leung TW, Cheung F, Ho KP, Cheung CH, Chan AS: Superoxide anion is involved in the early apoptosis mediated by Gleditsia sinensis fruit extract. Int J Mol Med 2004, 13:909-913.

19. Chui CH, Lau FY, Chan AS, Cheng GY, Wong RS, Lai KB, Kok SH, Yeung TT, Teo IT, Yau MY, Cheung F, Cheung CH, Tang JC: Gleditsia sinensis fruit extract-induced apoptosis involves changes of reactive oxygen species level, mitochondrial membrane depolarization and caspase 3 activation. Int J Mol Med 2005, 15:539-543.

20. Huang H-L, Chen C-C, Yeh C-Y, Huang R-L: Reactive oxygen species mediation of Baizhuinduced apoptosis in human leukemia cells. J Ethanopharmacol 2005, 97:21-29.

21. Kwon K-B, Kim E-K, Shin B-C, Seo E-A, Park J-W, Kim J-S, Park B-H, Ryu D-G: Induction of apoptosis by takrisodokyeum through generation of hydrogen peroxide and activation of caspase-3 in HL-60 cells. Life Sci 2003, 73:1895-1906. 
22. Johnson MK, Loo G: Effects of EGCG and quercetin on oxidative damage to cellular DNA. Mut Res 2000, 459:211-218.

23. Erba D, Riso P, Colombo A, Testolin G: Supplementation of Jurkat T cells with green tea extract decreases oxidative damage due to iron treatment. J Nutr 1999, 129:2130-2134.

24. Rice-Evans C: Implications of the mechanism of action of tea polyphenols as antioxidants in vitro for chemoprevention in humans. Proc Soc Exp Biol Med 1999, 220:262-266.

25. Bhimani RS, Troll W, Grunberger D, Frenkel K: Inhibition of oxidative stress in HeLa cells by chemopreventative agents. Cancer Res 1993, 53:4528-4533.

26. Lin J-K, Chen PC, Ho C-T, Lin-Shiau S-Y: Inhibition of xanthine-oxidase and suppression of intracellular reactive oxygen species in HL-60 cells by theaflavin-3,3'-digallate, (-)epigallocatechin-3-gallage, and propyl gallate. J Agric Food Chem 2000, 48:2736-2743.

27. Jagdeo J, Brody N: Complementary antioxidant function of caffeine and green tea polyphenols in normal human skin fibroblasts. J Drugs Dermatol 2011, 10:753-61.

28. Han KC, Wong WC, Benzie IF: Genoprotective effects of green tea (Camellia sinensis) in human subjects: results of a controlled supplementation trial. Br J Nutr 2011, 105:171-9.

29. Yamamoto T, Hsu S, Lewis J, Wataha J, Dickinson D, Singh B, Bollag WB, Lockwood P, Ueta E, Osaki T, Schuster G: Green tea polyphenol causes differential oxidative environments in tumor versus normal epithelial cells. J Pharmacol Exp Therap 2003, 307:230-236.

30. Elbling L, Herbacek I, Weiss R-W, Jantschitsch C, Micksche M, Gerner C, Pangratz H, Grusch M, Knasmüller S, Berger W: Hydrogen peroxide mediates EGCG-induced antioxidant protection in human keratinocytes. Free Radical Biol Med 2010, 49:1444-1452.

31. Groeger G, Quiney C, Cotter TG: Hydrogen peroxide as a cell survival signaling molecule. Antioxid Redox Signaling 2009, 11:2655-71. 